\title{
Asosiasi Adversity Quotient dengan Hasil Belajar Matematika Peserta Didik Jenjang SMP
}

\author{
Nurul Huda*, Damar Damar \\ Guru Matematika, SMP Negeri 4 Cikarang Selatan, Indonesia \\ *nurul.bok55@gmail.com
}

\begin{tabular}{|c|c|}
\hline Article Info & Abstract \\
\hline $\begin{array}{l}\text { Received } \\
04 \text { February } 2021\end{array}$ & $\begin{array}{l}\text { The purpose of this study was to determine whether there is a } \\
\text { relationship between the students' adversity questions and the } \\
\text { mathematics learning outcomes. This type of research is a quantitative } \\
\text { research with correlational techniques. The research sample that was }\end{array}$ \\
\hline $\begin{array}{l}\text { Revised } \\
05 \text { March } 2021\end{array}$ & $\begin{array}{l}\text { selected randomly to } 50 \text { students. The instrument to measure the } \\
\text { adversity quotient variable used a questionnaire with a Likert scale } \\
\text { and the variable instrument of mathematics learning outcomes used a }\end{array}$ \\
\hline $\begin{array}{l}\text { Accepted } \\
10 \text { April } 2021\end{array}$ & $\begin{array}{l}\text { multiple-choice form test, that had been tested for validity and } \\
\text { reliability. The requirements test performed showed normal analysis } \\
\text { results (Lilliefors test) and homogeneous (Fisher's test). The }\end{array}$ \\
\hline Keywords & $\begin{array}{l}\text { regression linearity test results of the regression line equation } \\
\hat{Y}=1,947+0,795 X . \text { The test results used product trials when the } \\
r=0,605 \text { was obtained. Reinforced the degree of significance with the }\end{array}$ \\
\hline Adversity Questiont & test obtained the $t_{\text {value }}=5,267>2,01=t_{\text {table. }}$ This research conclusion \\
\hline Junior High School & that there is a significant positive relationship between adversity \\
\hline $\begin{array}{l}\text { Learning Outcome } \\
\text { Mathematics }\end{array}$ & $\begin{array}{l}\text { quotient and mathematics learning outcomes of seventh grade students } \\
\text { at SMP Negeri } 4 \text { Cikarang Selatan with a contribution of } 36,6 \% \text {. }\end{array}$ \\
\hline
\end{tabular}

How to Cite:

Huda, N., \& Damar, D. (2021). Hubungan Antara Adversity Quotient Dengan Hasil Belajar

Matematika Peserta Didik Jenjang SMP. Journal of Instructional Mathematics, 2(1),

$10-20$.

\section{PENDAHULUAN}

Menghadapi kesulitan diperlukan adanya "daya juang" sehingga mampu menjadikan kesulitan sebagai tantangan dan peluang. Kemampuan memecahkan masalah, daya juang menghadapi masalah, dan keberanian mengambil risiko merupakan salah satu faktor yang mempengaruhi kesuksesan (Yuni, 2018). Seseorang yang mempunyai daya juang yang kuat dapat menilai tekanan, baik fisik maupun mental, persaingan, permasalahan, dan hal-hal yang tidak terduga sebagai suatu peluang. Bahkan menghadapi ancaman-ancaman sebagai hal yang bersifat sementara, sehingga tetap bertahan dan mempunyai harapan. Hal ini mengantarkan seseorang untuk mencurahkan segala kemampuan dan potensi agar permasalahan tersebut segera teratasi. Sebaliknya, individu yang mempunyai daya juang yang rendah akan merespon kesulitan sebagai hal yang bersifat menetap, tidak dapat dirubah sehingga melahirkan sikap ketidakberdayaan (helplesness). adversity quotient merupakan kemampuan yang dimiliki seseorang dalam mengamati kesulitan dan mengolah kesulitan tersebut dengan kecerdasan yang dimiliki sehingga menjadi sebuah tantangan untuk diselesaikan (Stoltz, 2010).

Hasil wawancara dengan guru mata pelajaran matematika di SMP Negeri 4 Cikarang Selatan yang mengampu mata pelajaran matematika kelas VII diperoleh 
informasi bahwa terdapat $63 \%$ peserta didik yang selalu merasa cemas dan tegang saat mengikuti pelajaran matematika. Beberapa peserta didik juga merasa bahwa dirinya tidak mempunyai kelebihan dalam pelajaran matematika, merasa cemas jika menghadapi tes, sering khawatir jika mendapat giliran maju ke depan kelas, dan berdampak mudah menyerah apabila menghadapi soal-soal yang sulit. Data awal dari hasil wawancara tersebut dapat menunjukkan bahwa masih ada sebagian peserta didik "merasa kesulitan memahami kecerdasannya" dalam menyelesaikan permasalahan matematika. dalam bahasa Inggris disebut low adversity quotient. Permasalahan siswa dalam belajar matematika inilah yang akan diteliti, sehingga siswa diberikan pengalaman dan informasi dengan memahami kecemasan yang mereka rasakan dan alami bukanlah suatu ancaman, namun dapat diubah menjadi peluang.

Pada proses belajar mengajar, peserta didik dituntut untuk mampu mengatasi segala permasalahan, kesulitan dan hambatan yang sewaktu-waktu muncul (Ruseffendi, 2010; Slameto, 2013), terutama saat menyelesaikan masalah matematika. Maka adversity quotient dinilai penting untuk dimiliki. Adversity quotient sebagai kecerdasan seseorang dalam menghadapi kesulitan atau permasalahan dalam membantu peserta didik meningkatkan potensi diri dan menjalankan kehidupan yang lebih baik. Lebih dari itu adversity quotient dapat pula sebagai pembinaan mental bagi peserta didik untuk menghindari masalah psikologis. Dengan memiliki adversity quotient, peserta didik dinilai lebih mampu melihat dari sisi positif, lebih berani mengambil risiko, sehingga tuntutan dan harapan dijadikan sebagai dukungan, serta keberadaan di kelas merupakan peluang untuk mencapai hasil belajar yang maksimal. Berdasarkan paparan tersebut, maka penulis tertarik untuk mengetahui adakah hubungan antara adversity quotient dengan kemampuan penalaran matematika? Dan seberapa besar hubungan antara adversity quotient dengan kemampuan penalaran matematis?

Tujuan penelitian diharapkan dapat dijadikan sebagai informasi mengenai hasil belajar peserta didik, dan sebagai rujukan dalam mengambil kebijakan, serta dapat memberikan intervensi bagi peserta didik yang mempunyai low adversity quotient. Sedangkan bagi peserta didik dapat membantu mereka mengetahui tingkat kendalinya dalam menghadapi kesulitan sebagai salah satu faktor keberhasilan, sehingga peserta didik tidak hanya meningkatkan kecerdasan intelektual, melainkan juga kecerdasan menghadapi kesulitan (kecerdasan emosional).

\section{Adversity Quotient}

Adversity dalam kamus Bahasa Inggris berarti kesengsaraan, kemalangan, kesulitan, kendala, atau ketidakberuntungan (Echols \& Shadily, 2003). Sedangkan quotient diartikan sebagai kemampuan atau kecerdasan. Istilah adversity quotient diambil dari konsep yang dikembangkan oleh Paul G. Stoltz, presiden PEAK Learning, Inc. seorang konsultan di dunia kerja dan pendidikan berbasis skill. Menurut Stoltz (2010) adversity quotient merupakan kemampuan yang dimiliki seseorang dalam mengamati kesulitan dan mengatasi kesulitan tersebut dengan kecerdasan yang dimiliki sehingga menjadi sebuah tantangan untuk diselesaikan. Namun demikian adversity quotient sebenarnya sebagai suatu potensi, dimana dengan potensi ini seseorang dapat mengubah hambatan atau kesulitan yang dihadapi menjadi peluang. Secara umum adversity quotient merupakan kemampuan individu dalam menggunakan kecerdasannya untuk mengarahkan dan 
mengubah cara berpikir serta bertindak ketika menghadapi hambatan dan kesulitan yang dapat menyengsarakannya (Hidayat, Wahyudin \& Prabawanto, 2018). Adversity quotient dapat berguna untuk memprediksi kinerja, motivasi, pemberdayaan, kreativitas, produktivitas, pembelajaran, energi, harapan, kebahagiaan, vitalitas, kesehatan emosional, kesehatan fisik, ketekunan, keuletan, sikap, umur panjang dan respon terhadap perubahan (Phoolka \& Kaur, 2012). Intinya berdasarkan pendapat Stoltz (2010), Hidayat (2018), dan Phoolka \& Kaur (2012), adversity quotient merupakan kemampuan mengubah ancaman, ketakutan menjadi peluang. Melalui adversity quotient dapat mengindeks seberapa kuat seseorang dapat menahan dan mengatasi kesulitan dengan kemampuan yang dimilikinya.

Suroso (2007) berpendapat bahwa, adversity quotient merupakan kemampuan seseorang dalam menggunakan kecerdasannya untuk mengarahkan, mengubah cara berpikir dan tindakannya ketika menghadapi hambatan dan kesulitan yang bisa menyengsarakan dirinya. Adversity quotient secara ringkas, yaitu sebagai kemampuan seseorang untuk menghadapi masalah. Beberapa definisi tentang adversity quotient yang cukup beragam, terdapat fokus atau titik tekan, yaitu kemampuan yang dimiliki seseorang, baik fisik ataupun psikis dalam menghadapi problematika atau permasalahan yang sedang dialami (Leman, 2007; Abdurrahman, 2013). Kesuksesan seseorang dalam menjalani kehidupan terutama ditentukan oleh tingkat adversity quotient yang dimilikinya (Stoltz, 2010).

Menurut Stoltz (2010), adversity quotient tersebut terwujud dalam tiga bentuk yaitu: (1) Kerangka kerja konseptual yang baru untuk memahami dan meningkatkan semua segi kesuksesan; (2) Suatu ukuran untuk mengetahui respon seseorang terhadap kesulitan; (3) Serangkaian alat untuk memperbaiki respon seseorang terhadap kesulitan. Adversity quotient mampu memprediksi seseorang mengenai tampilan motivasi, pemberdayaan, kreativitas, produktivitas, pembelajaran, energi, harapan, kegembiraan, vitalitas dan kesenangan, kesehatan mental, kesehatan jasmani, daya tahan, fleksibilitas, perbaikan sikap, daya hidup, dan respon (Hidayat, 2017). Prediksi mengenai hal-hal tersebut kemudian akan dapat memperkirakan siapa yang mampu bertahan mengatasi kesulitan dan memperkirakan siapa yang semakin tidak berdaya atas kesulitan yang dihadapi.

Adversity quotient juga dapat membantu individu memperkuat kemampuan dan ketekunan dalam menghadapi tantangan hidup sehari-hari dengan tetap berpegang pada prinsip-prinsip dan impian. Semakin tinggi tingkat adversity quotient semakin besar kemungkinan seseorang untuk bersikap optimis, dan inovatif dalam memecahkan masalah (Hidayat dkk., 2018). Diasumsikan sebaliknya, semakin rendah tingkat adversity quotient seseorang semakin mudah seseorang untuk menyerah, menghindari tantangan dan mengalami stres. Pernyataan ini sesuai dengan hasil penelitian Supardi (2013) yang berhasil membuktikan bahwa ada pengaruh positif dan signifikan adversity quotient terhadap prestasi belajar matematika siswa SMP. Menurut konsep ini bisa terwujud dalam tiga bentuk yaitu: 1) sebagai kerangka konseptual baru untuk memahami dan meningkatkan semua aspek keberhasilan; 2) sebagai ukuran bagaimana seseorang merespon kemalangan; dan 3) sebagai perangkat alat untuk memperbaiki respon seseorang terhadap kemalangan. Dengan kata lain adversity quotient merupakan suatu kemampuan untuk dapat bertahan dalam menghadapi segala masalah ataupun kesulitan hidup. 
Stoltz (2010) membagi empat dimensi dasar yang akan menghasilkan kemampuan adversity quotient yang tinggi, yaitu:

1. Kendali (control)

Kendali berkaitan dengan seberapa besar seseorang mampu mengendalikan kesulitan-kesulitan yang dihadapinya dan sejauh mana individu merasakan bahwa kendali itu ikut berperan dalam peristiwa yang menimbulkan kesulitan. Semakin besar kendali yang dimiliki semakin besar kemungkinan seseorang untuk dapat bertahan menghadapi kesulitan dan tetap teguh dalam niat serta ulet dalam mencari penyelesaian. Demikian sebaliknya, jika semakin rendah kendali, akibatnya seseorang menjadi tidak berdaya menghadapi kesulitan dan mudah menyerah.

2. Daya tahan (endurance)

Dimensi ini lebih berkaitan dengan persepsi seseorang akan lama atau tidaknya kesulitan akan berlangsung. Daya tahan dapat menimbulkan penilaian tentang situasi yang baik atau buruk. Seseorang yang mempunyai daya tahan yang tinggi akan memiliki harapan dan sikap optimis dalam mengatasi kesulitan atau tantangan yang sedang dihadapi. Semakin tinggi daya tahan yang dimiliki oleh individu, maka semakin besar kemungkinan seseorang dalam memandang kesuksesan sebagai sesuatu hal yang bersifat sementara dan orang yang mempunyai adversity quotient yang rendah akan menganggap bahwa kesulitan yang sedang dihadapi adalah sesuatu yang bersifat abadi, dan sulit untuk diperbaiki.

3. Jangkauan (reach)

Jangkauan merupakan bagian dari adversity quotient yang mempertanyakan sejauh manakah kesulitan akan menjangkau bagian lain dari individu. Reach juga berarti sejauh mana kesulitan yang ada akan menjangkau bagian-bagian lain dari kehidupan seseorang. Reach atau jangkauan menunjukkan kemampuan dalam melakukan penilaian tentang beban kerja yang menimbulkan stress. Semakin tinggi jangkauan seseorang, semakin besar kemungkinannya dalam merespon kesulitan sebagai sesuatu yang spesifik dan terbatas. Semakin efektif dalam menahan atau membatasi jangkauan kesulitan, maka seseorang akan lebih berdaya dan perasaan putus asa atau kurang mampu membedakan hal-hal yang relevan dengan kesulitan yang ada, sehingga ketika memiliki masalah di satu bidang dia tidak harus merasa mengalami kesulitan untuk seluruh aspek kehidupan individu tersebut.

4. Kepemilikan (origin and ownership)

Kepemilikan atau dalam istilah lain disebut dengan asal-usul dan pengakuan akan mempertanyakan siapa atau apa yang menimbulkan kesulitan dan sejauh mana seorang individu menganggap dirinya mempengaruhi dirinya sendiri sebagai penyebab asal-usul kesulitan. Orang yang skor origin (asal-usulnya) rendah akan cenderung berpikir bahwa semua kesulitan atau permasalahan yang datang itu karena kesalahan, kecerobohan, atau kebodohan dirinya sendiri, serta membuat perasaan dan pikiran yang akan merusak semangatnya.

Keempat dimensi ini yang akan diadopsi menjadi indikator instrumen angket untuk mengukur variabel adversity quotient.

Berdasarkan beberapa pengertian dan pendapat ahli tersebut, maka dapat disimpulkan bahwa adversity quotient yang dimaksud dalam penelitian ini adalah kemampuan peserta didik untuk bertahan menghadapi segala macam kesulitan pada 
mata pelajaran matematika sampai menemukan solusi atau jalan keluar dalam memecahkan berbagai macam permasalahan matematika, mereduksi hambatan dan rintangan dengan mengubah cara berpikir dan sikap peserta didik terhadap kesulitan yang dihadapi pada mata pelajaran matematika.

\section{Hasil Belajar Matematika}

Hasil belajar peserta didik dipengaruhi oleh beberapa faktor. Secara umum Slameto (2013) menyatakan bahwa faktor yang mempengaruhi hasil belajar mencakup faktor yang berada dalam diri peserta didik (faktor individu) dan dari luar diri individu (faktor situasi). Faktor individu meliputi kecerdasan intelegensi, sikap motivasi, kesiapan, dan kematangan. Selama ini kecerdasan intelegensi dinilai sebagai faktor utama keberhasilan seseorang termasuk berhasilnya peserta didik dalam menempuh pendidikan. Akan tetapi dengan mempertimbangkan karakteristik peserta didik yang berbeda, serta iklim kelas yang berbeda pula, maka dalam usaha pencapaian hasil belajar peserta didik belum cukup dengan intelegensi yang tinggi pula, tetapi juga bergantung pada kondisi individu atau peserta didik tersebut. Sedangkan faktor situasi yang dimaksud adalah faktor diluar diri peserta didik (individu), seperti: lingkungan, keluarga, guru, sarana, dan lain sebagainya. Faktor-faktor tersebut dapat membantu atau sebaliknya menyulitkan peserta didik pada saat proses kegiatan belajar mengajar.

Menurut Hamalik (2013), bila seseorang telah belajar akan terjadi perubahan tingkah laku pada orang tersebut. Perubahan tersebut meliputi: pengetahuan, emosional, pengertian, hubungan sosial, kebiasaan, jasmani, ketrampilan, etika atau budi pekerti, apresiasi, dan sikap. Makna pernyataan tersebut, apabila peserta didik dikatakan mengalami proses belajar jika pada dirinya telah terjadi perubahanperubahan kearah yang baik atau terjadinya peningkatan kualitas pada diri peserta didik yang meliputi: pengetahuan, emosional, pengertian, hubungan sosial dengan lingkungannya, kebiasaan, jasmani, keterampilan, etika dan moral, perubahan ini yang disebut hasil belajar (learning outcomes).

Bloom (dalam Jacobsen, Eggen \& Kauchak, 2014), membedakan hasil belajar menjadi tiga ranah, yaitu: ranah kognitif (pengetahuan), ranah afektif (sikap) dan ranah psikomotorik (keterampilan). Proses pembelajaran di sekolah saat ini, mengaplikasikan tipe hasil belajar kognitif lebih dominan dibandingkan dengan tipe hasil belajar afektif dan psikomotor. Sekalipun demikian tidak berarti bidang afektif dan psikomotor diabaikan. Persoalan yang perlu dikembangkan adalah bagaimana menjabarkan tipe hasil belajar tersebut sehingga jelas apa yang harus dinilai. Tipe hasil belajar psikomotor berkenaan dengan keterampilan atau kemampuan bertindak setelah ia menerima pengalaman belajar tertentu. Hasil belajar ini sebenarnya tahap lanjutan dari hasil belajar afektif yang baru tampak dalam kecenderungan untuk berperilaku (Thobroni \& Mustofa, 2011).

Berdasarkan uraian tersebut, dapat disimpulkan bahwa hasil belajar adalah perubahan tingkah laku kearah yang lebih baik meliputi aspek kognitif, afektif, dan psikomotorik sebagai hasil pengalaman belajar. Kecakapan atau kemampuan sebagai hasil belajar memungkinkan seseorang mampu melakukan perbuatan yang tidak dapat dilakukan sebelumnya. Perubahan yang terjadi akibat proses belajar tidak bersifat permanen, artinya suatu saat bisa bertambah atau berkurang. Jika dipelajari lebih lanjuta akan bertambah, atau sebaliknya. 


\section{METODE PENELITIAN}

Penelitian ini dilaksanakan di SMP Negeri 4 Cikarang Selatan. Waktu penelitian dilaksanakan pada semester genap tahun pelajaran 2019/2020 tepatnya pada bulan Mei-Juli 2020. Metode yang digunakan dalam penelitian ini menggunakan pendekatan kuantitatif dengan teknik korelasi (Arikunto, 2012, Creswell, 2010). Data penelitian dikumpulkan dengan menyebarkan angket dan tes hasil belajar matematika. Konstelasi masalah penelitian ini dapat digambarkan dalam bagan berikut.

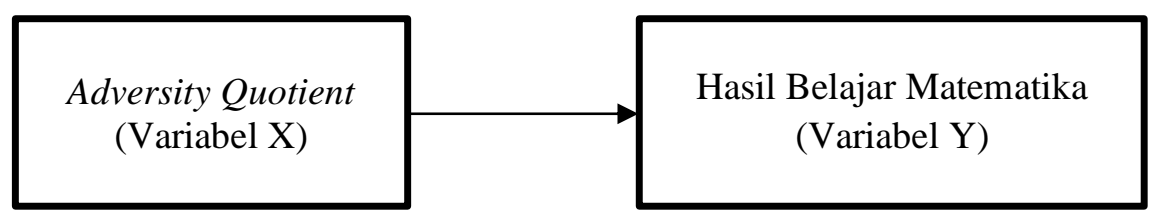

Gambar 1. Konstelasi Masalah Penelitian

Sampel penelitian adalah peserta didik kelas VII SMP Negeri 4 Cikarang Selatan sebanyak 50 orang yang dipilih dengan teknik random sampling dari populasi terjangkau kelas VII.2 sampai VII.4. Dari kelas VII.2 dan VII.3 dipilih 17 peserta didik, sedangkan dari kelas VII.4 dipilih 16 peserta didik. Peserta didik kelas VII.1 sebanyak 30 orang dijadikan sampel ujicoba instrumen. Mula-mula angket dibuat sebanyak 30 butir pernyataan, dan instrumen tes bentuk pilihan ganda 30 butir dengan empat pilihan jawaban. Diperoleh 26 butir instrumen angket yang valid dan reliabel yang digunakan sebagai alat pengumpul data variabel adversity quotient. Dari hasil uji validitas dan reliabilitas instrument tes untuk mengukur hasil belajar matematika diperoleh 25 butir soal bentuk pilihan ganda dengan 4 pilihan jawaban (a, b, c, dan d).

\section{HASIL DAN PEMBAHASAN}

Pada sub hasil dan pembahasana berikut, diuraikan secara lebih terperinci perolehan nilai hasil belajar matematika dan skor adversity quotient peserta didik kelas VII SMP Negeri Cikarang Selatan. Untuk lebih memahami temuan hasil penelitian akan di paparkan berdasarkan variabel bebas dan varibel terikat.

\section{Hasil Belajar Matematika (Variabel Terikat)}

Hasil belajar matematika peserta didik pada penelitian ini adalah sebagai variabel terikat. Setelah data diolah dengan uji-uji statistik, diperoleh rentang skor capaian hasil belajar matematika pada materi himpunan antara 40-88 dengan nilai rata-rata sebesar 65,12, median sebesar 66,33 dan modus sebesar 71,38, varians 164,72 serta simpangan baku 12,83 .

Untuk memperjelas data hasil belajar matematika yang diperoleh, dibuat diagram batang sebagaimana terlihat pada Gambar 2. 


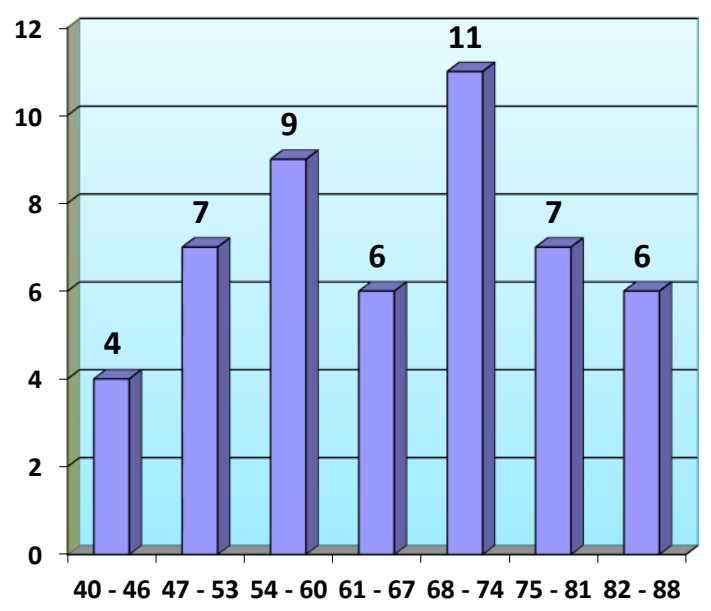

Gambar 2. Diagram Batang Hasil Belajar Matematika

Berdasarkan diagram batang pada Gambar 2 terlihat bahwa peserta didik yang memperoleh nilai di bawah nilai rata-rata sebanyak 20 peserta didik atau $40 \%$, peserta didik yang memperoleh nilai di sekitar nilai rata-rata sebanyak 6 peserta didik atau $12 \%$ dan kelompok peserta didik yang memperoleh nilai di atas nilai ratarata sebanyak 24 peserta didik atau $48 \%$. Data hasil belajar matematika diambil dari sampel yang berasal dari populasi yang berdistribusi normal. Hal ini dibuktikan dengan uji normalitas menggunakan uji Liliefors diperoleh nilai $L_{\text {hitung }}=0,0811$ dan $L_{\text {tabel }}=0,1252$ pada taraf signifikan $\alpha=0,05$ dan $N=50$. Karena $L_{\text {hitung }}<L_{\text {tabel }}$ maka dapat disimpulkan bahwa variabel terikat (hasil belajar matematika) berdistribusi normal.

\section{Skor Adversity Quotient (Variabel Bebas)}

Skor adversity quotient peserta didik diperoleh dari penyebaran 26 butir angket berupa pernyataan positif dan negatif yang mencakup 4 dimensi. Skor perolehan variable adversity quotient berada pada rentang skor 58-99 dengan nilai rata-rata sebesar 79,22, median sebesar 79,00 dan modus sebesar 77,90, varians 94,98 serta simpangan baku 9,75. Dari data yang diperoleh dibuat diagram pada Gambar 3.

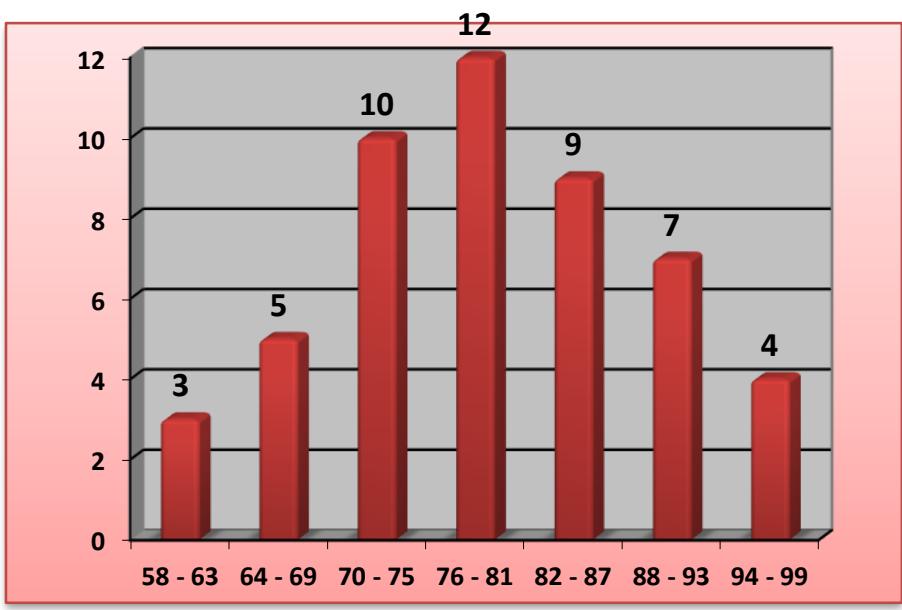

Gambar 3. Diagram Batang Skor Adversity Quotient 
Analisis hasil angket berdasarkan dimensi dan indikator variabel adversity quotient, dari empat dimensi yang diukur yaitu: (1) kontrol atau kendali, (2) asalusul dan pengakuan, (3) jangkauan, (4) daya tahan, diketahui bahwa dimensi yang memiliki rata-rata skor tertinggi yaitu dimensi kontrol atau kendali yaitu sebesar 3,15 dari rentang skala likert 1-4, diikuti dimensi daya tahan sebesar 3,14, dimensi jangkauan sebesar 3,09, dan dimensi asal-usul dan pengakuan sebesar 2,91.

Dilihat dari indikator, diketahui indikator yang memperoleh rata-rata skor tertinggi atau yang kuat yaitu indikator berani mengambil risiko sebesar 3,20, diikuti indikator mudah bangkit dari ketidakberdayaan sebesar 3,16, indikator mempunyai sifat optimisme sebesar 3,14, indikator menilai kesulitan atau kegagalan bersifat sementara dan indikator mampu memaksimalkan sisi positif dari situasi sulit sebesar 3,13, indikator mampu mengendalikan diri dalam menghadapi kesulitan sebesar 3,10, indikator melakukan pemetaan masalah dengan tepat sebesar 3,05, indikator memandang kesuksesan sebagai hasil kerja keras yang telah dilakukan sebesar 2,99, indikator bertanggung jawab atas terjadinya situasi sulit sebesar 2,89, dan indikator menempatkan rasa bersalah secara wajar sebesar 2,86. Data tersebut menunjukkan bahwa peserta didik kelas VII SMP Negeri 4 Cikarang Selatan memiliki adversity quotient pada dimensi kontrol atau kendali yang cukup baik. Hal ini sesuai dengan hasil penelitian adversity quotient yang ditemukan Hidayat (2017) yang diperoleh berdasarkan hasil analisis jawaban tertulis dan wawancara. Hasil pengukuran adversity quotient yang dilakukan Hidayat terhadap 38 siswa yang dijadikan sampel penelitian bahwa adversity quotient peserta didik tergolong baik dan tidak banyak beragam.

Data adversity quotient bersumber pada sampel yang berasal dari populasi berdistribusi normal. Hal ini dibuktikan dengan perhitungan uji Liliefors untuk variabel bebas yaitu adversity quotient diperoleh nilai $L_{\text {hitung }}=0,0859$ dan $L_{\text {tabel }}=0,1252$ pada taraf signifikan $\alpha=0,05$ dan $N=50$. Karena $L_{\text {hitung }}<L_{\text {table, dapat }}$ disimpulkan bahwa data adversity quotient berdistribusi normal.

Karena sampel diambil dari beberapa kelas, maka perlu dilakukan uji prasyarat uji homogenitas menggunakan uji Fisher (uji $F$ ). Diperoleh Uji homogenitas dua varians antara variabel $\mathrm{X}$ dan variabel $\mathrm{Y}, F_{\text {hitung }}=1,57$ dan $F_{0,05(49,49)}=1,61$. Karena $F_{\text {hitung }}<F_{\text {tabel }}$ dapat disimpulkan bahwa sampel mempunyai kondisi yang homogen.

Selanjutnya dilakukan uji regresi menggunakan ANAVA (Sudjana, 2009) untuk melihat hubungan antara kedua variable yang disajikan pada Tabel 1 berikut:

Tabel 1. Analisis Varians (ANAVA)

\begin{tabular}{ccccccc}
\hline Sumber & \multirow{2}{*}{$d k$} & \multirow{2}{*}{$J K$} & \multirow{2}{*}{$R J K$} & $F_{0}$ & \multicolumn{2}{c}{$F_{\text {tabel }}$} \\
Variansi & & & & & $5 \%$ & $1 \%$ \\
\hline Total & 50 & 7880,00 & 7880,00 & - & - & - \\
Reg (a) & 1 & 212552,00 & 212552,00 & - & - & - \\
Reg (b|a) & 1 & 2886,31 & 2886,31 & 27,74 & 4,04 & 7,19 \\
Sisa & 48 & 4993,69 & 104,04 & - & - & - \\
Tuna c & 22 & 2576,36 & 117,11 & 1,26 & 1,97 & 2,62 \\
Galat & 26 & 2417,33 & 92,97 & - & - & - \\
\hline
\end{tabular}

Pengujian signifikansi regresi pada Tabel 1 diketahui $F_{\text {hitung }}\left(F_{0}\right)$ sebesar 27,74 yang lebih dari $F_{\text {tabel }}(4,04)$ pada taraf signifikan $\alpha=0,05$. Hal ini berarti regresi signifikan. Hasil pengujian linearitas regresi memperlihatkan $\mathrm{F}$ hitung pada baris 
tuna cocok sebesar 1,26 yang kurang dari $F_{\text {tabel }}=1,97$ pada taraf signifikan $\alpha=0,05$. Dengan demikian, dapat dinyatakan bahwa persamaan regresi tersebut linier. Interpretasi dari model persamaan regresi $\hat{Y}=1,947+0,795 X$ berarti setiap perubahan skor adversity quotient peserta didik sebesar satu unit, hasil belajar matematika akan meningkat sebesar 0,795 unit pada arah yang sama dengan konstanta 1,947 (Sudjana, 2009). Hasil pengujian menentukan garis persamaan regresi disajikan dalam grafik garis pada Gambar 4 berikut ini:

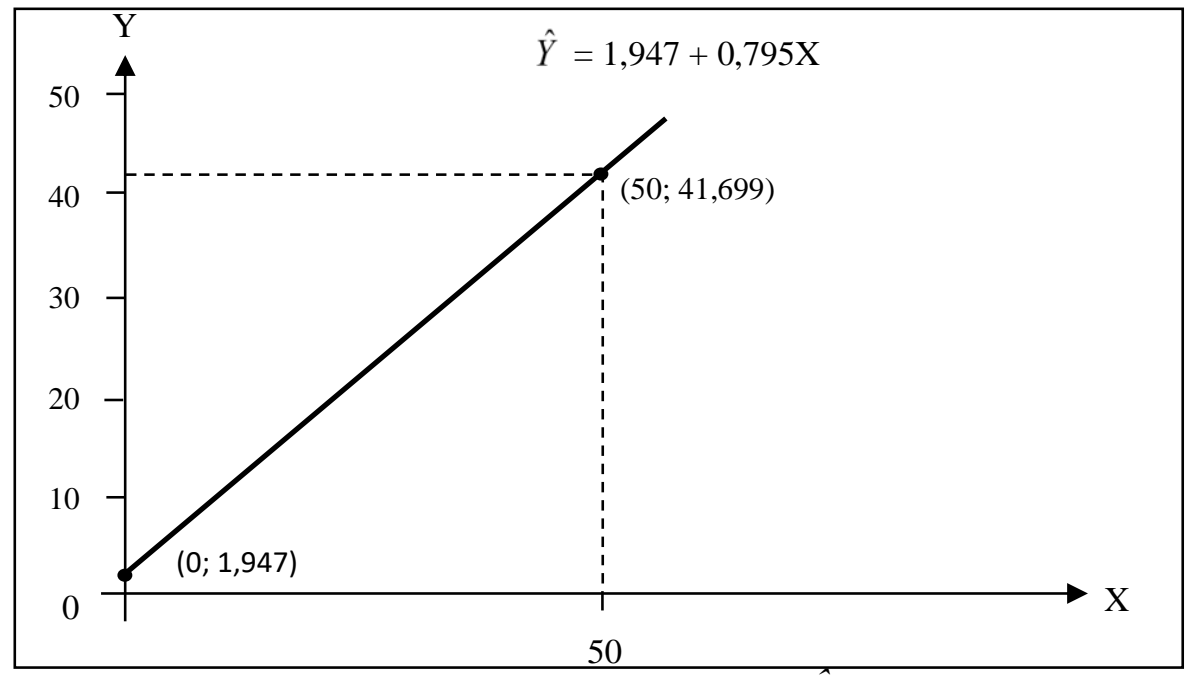

Gambar 4. Grafik Garis Persamaan Regresi $\hat{Y}=1,947+0,795 X$

\section{Uji Hipotesis}

Untuk menguji hipotesis digunakan rumus korelasi Product Moment dari Pearson. Dari hasil pengujian diperoleh koefisien korelasi antara adversity quotient dengan hasil belajar matematika peserta didik sebesar $r=0,605$. Hasil tersebut jika dikaitkan dengan angka indeks korelasi product moment masuk dalam kategori hubungan yang kuat. Untuk mengetahui seberapa besar persentase hubungan antara adversity quotient dengan hasil belajar matematika peserta didik dapat dilakukan dengan menghitung koefisien determinasi menggunakan rumus sebagai berikut:

$$
K D=r^{2} \times 100 \%=(0,605)^{2} \times 100 \%=0,3660 \times 100 \%=36,60 \% .
$$

Maka pengaruh atau kontribusi adversity quotient dengan hasil belajar matematika adalah $36,60 \%$, sedangkan $63,40 \%$ diberikan kontribusinya oleh faktor lain. Hasil penelitian ini sejalan dengan hasil penelitian Hidayat (2017), yang menemukan bahwa kemampuan pemecahan masalah matematis dapat teratasi bagi siswa yang memiliki adversity quotient quitters. Lebih lanjut temuan penelitian Hidayat dkk. yang dilakukan pada siswa SMA di Cimahi Bandung, ada pengaruh positif adversity quotient terhadap keterampilan penalaran matematis kreatif siswa SMA. Sejalan juga dengan penelitian Santos (2012) menemukan bahwa adversity quotient dapat dilatih sehingga dapat menekan tingkat stress seseorang. Santos meneliti guru-guru sekolah luar biasa yang membimbing dan mendidik anak-anak berkebutuhan khusus. Pekerjaan guru sekolah berkebutuhan khusus tentu sangat tinggi tingkat stressnya. Melalui adversity quotient yang dilatih, berhasil menurunkan tingkat stress guru-guru berkebutuhan khusus di Maricopa School 
District Arizona Amerika Serikat. Perbedaan kedua penelitian sebelumnya dengan penelitian ini adalah pada sampel yang diteliti. Santos meneliti guru-guru disekolah berkebutuhan khusus, Hidayat meneliti siswa SMA, sedangkan penelitian ini dilakukan pada siswa SMP. Tentunya pada materi pelajaran matematika yang berbeda pula. Namun penelitian ini dan sebelumnya sama sama menemukan bahwa adversity quotient yang dilatih dan dikontrol mempunyai pengaruh positif terhadap rasa cemas menghadapi masalah.

Selanjutnya hasil perhitungan korelasi product moment dikuatkan dengan perhitungan signifikansi koefisien korelasi untuk mengetahui signifikansi hubungan antara adversity quotient dengan hasil belajar matematika menggunakan uji $t$ ( $t$-student) sebagai berikut:

$$
t=\frac{r \sqrt{n-2}}{\sqrt{1-r^{2}}}=\frac{0,605 \sqrt{50-2}}{\sqrt{1-0,605^{2}}}=5,267
$$

Berdasarkan hasil perhitungan uji $t$ pada taraf signifikansi 0,05 dan $d k=48$, diperoleh $t_{\text {hitung }}=5,267$ dan $t_{\text {tabel }}=2,01$. Karena $t_{\text {hitung }}=5,267>t_{\text {tabel }}=2,01$ maka terdapat hubungan positif yang signifikan adversity quotient dengan hasil belajar matematika peserta didik kelas VII di SMP Negeri 4 Cikarang Selatan.

\section{KESIMPULAN}

Berdasarkan hasil penelitian yang telah dilaksanakan di SMP Negeri 4 Cikarang Selatan, bahwa terdapat terdapat hubungan yang signifikan antara adversity quotient dengan hasil belajar matematika peserta didik kelas VII di SMP Negeri 4 Cikarang Selatan. Semakin tinggi tingkat adversity quotient (kecemasan, kesulitan) siswa, maka semakin tinggi hasil belajar matematikanya. Hal ini ditunjukan dengan persamaan garis regresi linier. Dari hasil wawancara, diperoleh pernyataan bahwa ketika peserta didik semakin khawatir maka mereka semakin menyiapkan diri untuk lebih giat belajar matematika, agar hasil belajar mereka tidak rendah atau jelek. Kesimpulan penelitian hipotesis nol ditolak atau hipotesis penelitian diterima. Hal ini berarti terdapat hubungan yang positif dan signifikan antara adversity quotient dengan hasil belajar matematika peserta didik. Adversity quotient memberikan kontribusi sebesar 36,60\% terhadap hasil belajar matematika, sedangkan 63,40\% diberikan kontribusnya oleh faktor lain yang tidak diteliti pada penelitian ini.

\section{UCAPAN TERIMA KASIH}

Peneliti mengucapkan terimakasih kepada Ibu Dr. Yatha Yuni, M.Pd. yang telah berbagi ilmu dan membimbing dalam penelitian, serta mengarahkan penulisan laporan hasil penelitian, serta membimbing dalam membuat artikel ini sampai cara submit artikel. Semoga ilmu yang ibu bagikan menjadi ilmu yang bermanfaat. Peneliti juga berterima kasih kepada Kepala SMP Negeri 4 Cikarang Selatan yang telah berkenan wilayah kerjanya dijadikan tempat penelitian, serta memberikan informasi penting dalam membantu proses penelitian ini. Dan atas kebaikan Ibu serta Bapak semoga mendapat pahala berlipat ganda dari Allah SWT. 


\section{REFERENSI}

Abdurrahman, M. (2013). Pendidikan Bagi Anak Berkesulitan Belajar. Jakarta: Rineka Cipta.

Arikunto, S. (2012). Prosedur Penelitian Suatu Pendekatan Praktik. Jakarta: Rineka Cipta.

Creswell, J. W. (2010). Research Design, Pendekatan Kualitatif, Kuantitaif, dan Mixed (Terjemahan Achmad Fawaid). Yogyakarta: Pustaka Pelajar.

Echols, J. M., \& Shadily, H. (2003). Kamus Inggris Indonesia. Jakarta: Gramedia Pustaka Utama.

Hamalik, O. (2013). Proses Belajar Mengajar (Cetakan ke lima). Jakarta: Bumi Aksara.

Hidayat, W. (2017). Adversity quotient dan penalaran kreatif matematis siswa sma dalam pembelajaran argument driven inquiry pada materi turunan fungsi. KALAMATIKA: Jurnal Pendidikan Matematika, 2(1), 15-28.

Hidayat, W., Wahyudin, W., \& Prabawanto, S. (2018). Improving students' creative mathematical reasoning ability students through adversity quotient and argument driven inquiry learning. Journal of Physics: Conference Series, 948(1), 012005.

Jacobsen, D. A., Eggen, P., \& Kauchak, D. (2014). Methods for Teaching (Metodemetode Pengajaran Meningkatkan Belajar Peserta Didik TK-SMA). Yogyakarta: Pustaka Pelajar.

Leman. (2007). The Best of Chinese Life Philosophies. Jakarta: Gramedia Pustaka Utama.

Santos, M. C. J. (2012). Assessing the effectiveness of the adapted adversity quotient program in a special education school. Researchers World, 3(4), 13.

Phoolka, E. S., \& Kaur, N. (2012). Adversity Quotient: A new paradigm to explore. Contemporary Business Studies, 3(4), 67-78.

Ruseffendi, E. T. (2010). Pengajaran Matematika Modern. Bandung: Tarsito.

Slameto. (2013). Belajar dan Faktor-faktor yang Mempengaruhinya. Jakarta: Rineka Cipta.

Stoltz, P. G. (2010). Adversity Quotient: Mengubah Hambatan Menjadi Peluang, Alih Bahasa: Hermaya. Jakarta: PT. Grasindo.

Sudjana. (2009). Metoda Statistika. Bandung: Tarsito.

Supardi, U. S. (2013). Pengaruh adversity quotient terhadap prestasi belajar matematika. Jurnal Formatif, 3(1), 61-71.

Suroso, F. N. (2007). Psikologi Islami. Yogyakarta: Pustaka Pelajar.

Thobroni, M., \& Mustofa, A. (2011). Belajar \& Pembelajaran, Pengembangan Wacana dan Praktik Pembelajaran dalam Pembangunan Nasional. Yogyakarta: Ar-Ruzz Media.

Yuni, Y. (2018). The attitude of risk taking Islamic junior high school (MTs) students in learning mathematics. Journal of Physics: Conference Series, 1013(1), 012113. 